Sociedad de Estudios de Historia Agraria - Documentos de Trabajo

DT-SEHA n. 1903

Julio de 2019

www.seha.info

\title{
REVISITING WATER AND ECONOMIC GROWTH FROM A LONG-TERM PERSPECTIVE
}

\author{
Rosa Duarte* \\ Vicente Pinilla* \\ Ana Serrano*
}

* Universidad de Zaragoza e Instituto Agroalimentario de Aragón Contacto: vpinilla@unizar.es

(C) Julio de 2019, Rosa Duarte, Vicente Pinilla y Ana Serrano

ISSN: 2386-7825 


\begin{abstract}
Water use has increased notably throughout the world over the last 250 years. The industrial revolution and the long-term economic growth processes, first experienced by Western countries, and then by many other regions, put growing pressure on water resources. If we focus on economic growth, structural change and the rise in per capita income have been key factors in explaining water use trajectories. In addition, population growth has also boosted water needs worldwide. On the contrary, the increase in water use efficiency, mostly driven by technological developments, but also by improved institutions and environmental awareness, has slowed down water requirements. In this general context, our study aims to analyse the drivers of water use from a long-term perspective. More specifically, we analyse world and regional trends in water use over the last century and their relationships with population, economic growth and technological change. We pay particular attention to the second half of the last century and the twenty-first century, given the rising demands linked to trade, the emergence of new economies with increasing per capita income and demands and the smooth technological change observed in developed countries.
\end{abstract}

Keywords: water history, water use drivers, water long-term trends

JEL CODES: N50, Q15, Q25, Q56

\title{
Resumen
}

El uso del agua ha aumentado notablemente en todo el mundo en los últimos 250 años. La revolución industrial y los procesos de crecimiento económico a largo plazo, experimentados primero por los países occidentales y luego por muchas otras regiones, han ejercido una presión creciente sobre los recursos hídricos. Si nos centramos en el crecimiento económico, el cambio estructural y el aumento del ingreso per cápita han sido factores clave para explicar las trayectorias del uso del agua. Además, el crecimiento de la población también ha impulsado las necesidades de agua en todo el mundo. Por el contrario, el aumento de la eficiencia en el uso del agua, impulsado principalmente por los avances tecnológicos, pero también por la mejora de las instituciones y la concienciación medioambiental, ha ralentizado las necesidades de agua. En este contexto general, nuestro estudio pretende analizar los factores impulsores del uso del agua desde una perspectiva de largo plazo. Más específicamente, analizamos las tendencias mundiales y regionales en el uso del agua durante el último siglo y sus relaciones con la población, el crecimiento económico y el cambio tecnológico. Prestamos especial atención a la segunda mitad del siglo pasado y al siglo XXI, dadas las crecientes demandas vinculadas al comercio, el surgimiento de nuevas economías con crecientes ingresos per cápita y demandas y el suave cambio tecnológico que se observa en los países desarrollados.

Palabras clave: historia del agua, factores impulsores del uso de agua, tendencia a largo plazo en el uso de agua 


\section{Introduction ${ }^{1}$}

Nowadays there is no doubt about the vital and irreplaceable role that water plays in sustainable development and its importance for socioeconomic development, sustainability of ecosystems and humanity. Water is also crucial for improving the health, welfare and productivity of nations (United Nations, 2014). However, although it is a finite and irreplaceable resource, the demand for water has grown steadily over the last century. This growth is strongly linked to the development processes experienced by the world regions, increasingly generating situations of overexploitation of freshwater resources, which poses a serious threat to food security (Falkenmark, 2013) and, in short, to humanity.

According to McNeill (2000), freshwater increased forty-fold between 1700 and 1900 and seven-fold in the twentieth century. Vorösmarty et. al. (2005) highlight that global water withdrawal increased at a rate of $17 \%$ per decade between 1960 and 2000, and eventually doubled in 2000. This trend has been diminishing in North America and Europe since the 1980s, while it has been increasing in other regions of the world such as Southeast Asia, South America, Africa or Oceania. Recent studies estimate that global water withdrawal will grow to as much as 6900 billion $\mathrm{m}^{3} /$ year in 2030, from the current $4500 \mathrm{~m}^{3} /$ year (McKinsey, 2009), with significant inequalities between areas in the world. The United Nations estimates that about 1.9 billion people currently live in water-scarce areas and if current trends continue, this figure will reach 3 billion by 2050 . Even more worrying assessments conclude that the limits for global freshwater use are fast being reached and the predictions and scenarios for the short and medium term are far from optimistic about the capacity of societies to achieve sustainable levels of water consumption (Rockström et al., 2009; Gerten, 2013). In this regard, Distefano and Kelly (2017) also show that income growth under the IPCC scenario is not sustainable considering the water limits.

There is quite a high level of consensus regarding the fact that human actions have become the main driver of global environmental change (Rockström et al., 2009). Along the same lines, Meybeck (2003) indicates the increasing acknowledgement of the role of societal and economic drivers, such as population, education, urbanisation, industrialisation, water engineering, and international environmental regulation in controlling continental aquatic systems. The UNESCO report "Five stylised scenarios" (Gallopín, 2012) identifies demography, economy, technology (including water infrastructures), and ecosystems and land use (including here agriculture) as major potential drivers of current and future water withdrawals. These factors are also identified in other recent papers such as Duarte et al. (2014a, 2019), Distefano et al. (2018) and Solino (2019), among others. In parallel, we must also acknowledge the growing importance of social behaviours and governance at different scales to build a global awareness, allowing the articulation of global policies to anticipate and alleviate water pressures.

Despite the importance of identifying and understanding the dynamics of these factors and their contribution to current water shortages, studies such as Kummu et. al.

\footnotetext{
${ }^{1}$ This work has been supported by the Ministry of Science, Innovation and Universities of the Spanish Government (projects: PGC2018-095529-B-I00 and ECO2016-74940), by the Department of Science, Technology and Universities of the Government of Aragon (Reference Groups S55_17R and S40_17R), and by Feder 2014-2020 "Building Europe from Aragon".
} 
(2016) recognise that the historical development of these trajectories has been much less studied. Economic literature has barely focused on how long-term economic growth has modelled the size, geographical distribution and irreversibility of water impacts (Tello and Ostos, 2012; Duarte et.al, 2014a; 2014b; 2016; 2019; Cazcarro et al. 2015). This work addresses this issue. More specifically, it aims to shed light on the identification of the factors that have contributed over the last century to the growing demand for water and the current water scarcity, paying special attention to the evolution of the main social and economic determinants. The identification of long-term regularities and the study of the main changes in patterns of consumption and production over time can help to identify possible future bottlenecks or anticipate solutions based on the behaviour already observed. In this analysis, a global and integrated economic view is needed.

This work explores long-term trends in water demands throughout the twentieth century to the present day, and critically discusses the contribution of the most relevant factors behind the current water demands worldwide. An integrated economic and global perspective to understand the co-evolution of these drivers, their interrelationships and the contribution to global water trends is used.

The rest of the working paper is structured as follows: Section 2 explains the main historical trends in water use. Then, Section 3 discusses the most important factors driving long term water use. First, we focus on the role played by population growth. Secondly, we move to the assessment of economic development as a determinant of historical water use increase. Third, we study globalisation as a driving factor behind water use. Next, we look at the impact of water intensity changes. Section 4 analyses the most significant responses from the supply side and finally, the work ends with the main conclusions.

\section{Long-term trends in water use}

Global water use increased notably from 1900 to 2010. As Figure 1 (left axis) shows, this growth was smooth until the mid-twentieth century and more intense from 1950 onwards. The continuous process of water use led to an approximate six-fold increase from 1900 to 2010, with strong annual growth rates - around 3\%, during the 1950s, 1960s and 1970s. From 1980, the growth continued, but it was more moderate. In per capita terms (right axis of Figure 1), the trend was similar until the 1980s, with per capita water use growing modestly from 1900 to 1950 and accelerating until 1980. Then, the trend reversed, and per capita water use began a downward trend, given the small growth in water use compared to population during these years. In light of the data, it seems clear that the pressures on global water resources continue to grow, even though each person in the world today uses the same amount of water as in 1960.

Figure 1 also depicts the historical trajectory of non-consumptive water use ${ }^{2}$ (also known as water withdrawal) in three world regions based on the information provided by Steffen et al. (2015). These authors offer long term water use data for the aggregates ${ }^{3}$ of

\footnotetext{
${ }^{2}$ According to AQUASTAT, water withdrawal refers to "the water that has been removed from its source for a specific use. There is an important distinction between consumptive water use and non-consumptive water use. In this regard, consumptive water use is the part of water withdrawn from its source for use in a specific sector that will not become available for reuse because of evaporation, transpiration, incorporation into products, drainage directly to the sea or evaporation areas, or removal in other ways from freshwater resources".

${ }^{3}$ This world division has also been used in the next Sections.
} 
OECD countries (based on the 2010 classification), BRICS (Brazil, Russia, India, China and South Africa) and a region called ROW (Rest of the World) that comprises all other countries.

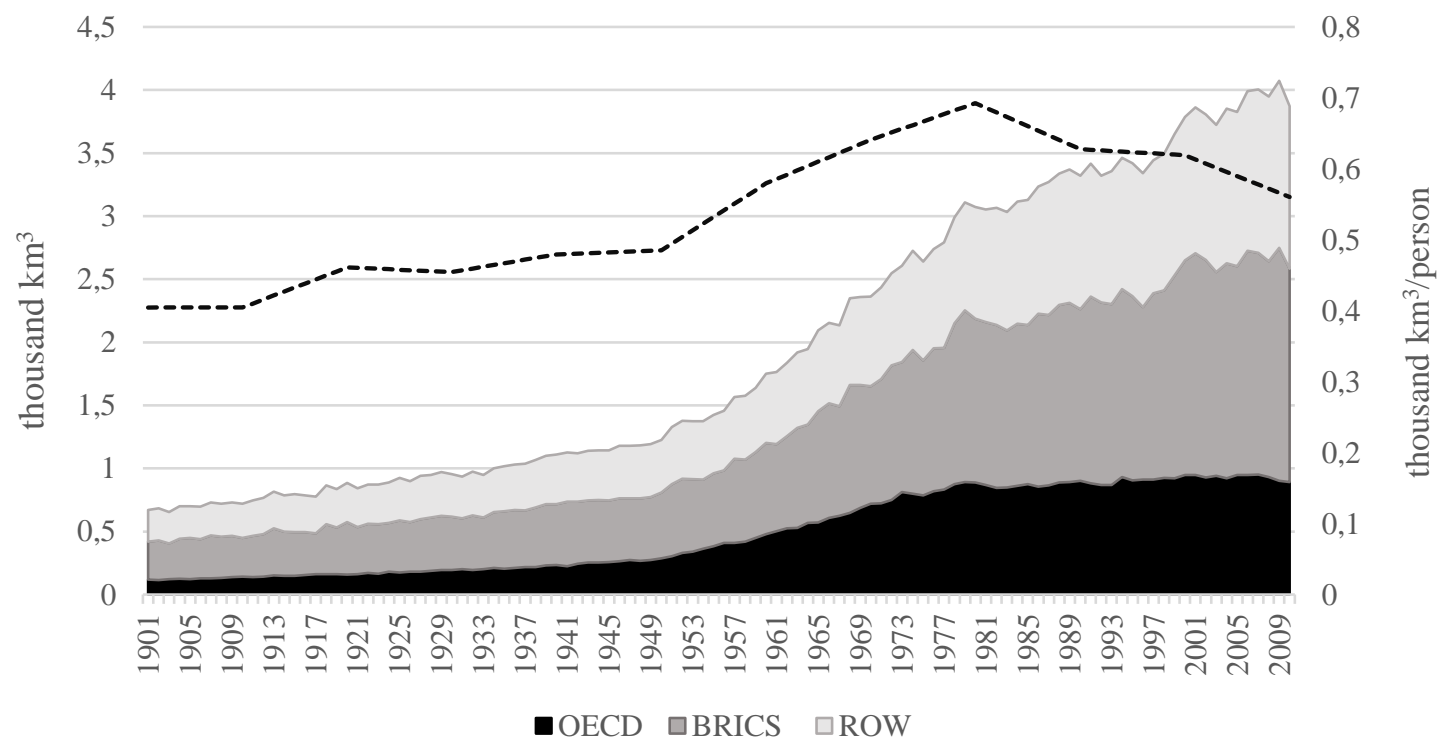

Figure 1: Water use (thousand km3) by groups of countries (left axis) and global water use per capita (thousand $\mathbf{k m}^{3}$ per person) (right axis), 1901-2010. Source: own elaboration from Steffen et al. (2015).

Despite that on average OECD areas display the smallest share of global water use (23\%), during the twentieth century the pressure that they put on water resources experienced the largest increase worldwide. Between 1900 and 2010, water use in OECD countries rose by a factor of seven. Over the first half of the twentieth century the water use of OECD countries grew at annual rate of $1.8 \%$, accelerating to $2.4 \%$ per year from 1950 to 2000 , especially during the 1960 s and 1970s. Subsequently, at the beginning of the twentieth first century, water use fell slightly in these countries. If we look at the specific data on countries taken from the FAO (2018a), the USA represents approximately $50 \%$ of total OECD water use from 1970. According to Donnelly and Cooley (2015), total water use in the USA peaked in 1980, remained stable between 1985 and 2005 and experienced a considerable fall from 2005 to 2010. This trend was also observed in per capita terms. Other OECD countries, such as Japan, Canada, Mexico, Germany or France with a considerable share in global water use, also experienced a fall, both in absolute and per capita terms. Although these trends seem to indicate that pressures on water resources in developed areas have tended to reduce in recent decades, we should bear in mind that these calculations only contemplate the resources extracted domestically. Thus, this measurement of water pressures does not contemplate the growing and large imports embodying water resources from other countries, mostly emerging and agricultural-based economies. Recent literature (Carr et al., 2012; Duarte et al., 2016; Tamea et al., 2014) highlights the need to account for the responsibility of consumption for environmental damage, going beyond the effects generated domestically 
and considering the externalisation of water impacts. This is particularly important given the rising global fragmentation of supply chains.

Moving on to the BRICS areas, the pattern is quite different. First, and although this group consists of only five countries - with $44 \%$ of total world population, it accounted for $43 \%$ of global water use between 1900 and 2010, on average. Second, considering the whole period analysed, we can observe a five-fold increase. Figure 1 shows a small increase in water use during the first half of the twentieth century that notably strengthened between 1950 and 1980. Subsequently, the pace of the growth reduced and then flattened from 2000. This was the case of China, which, according to Zheng et al. (2010), has experienced a deceleration in water use in recent years. Today China and India have the largest weight in water use (FAO, 2018a), higher than that of the USA. Both countries account for a large share of agricultural water use, reaching around $90 \%$ in India by 2010 (FAO, 2018a). The water use in the rest of the BRICS countries is less than a tenth of the water use in India or China. Meanwhile, the water use in Russia, which is highly associated to the industrial sector, decreased considerably during the nineties and the early years of the twenty-first century. Water use remained stable in South Africa from 1990. Nevertheless, it more than doubled in Brazil between 1987 and 2010, where it is mainly associated to irrigated agriculture (FAO, 2018a).

Finally, the heterogeneous group named ROW, which on average has a weight of $33 \%$ of global water use, also experienced moderate growth between 1900 and 1950. During the second half of the twentieth century this trend intensified, with annual growth rates being twice as high as those of 1900-1950. Contrary to the pattern seen for OECD countries and some BRICS areas, water use continued to grow significantly from 2000. We can highlight some particular cases as Northern Africa where food-producing countries are increasing water use in a context of severe scarcity. This is for example the case of Egypt, where water withdrawals nearly doubled between 1975 and 2010 (FAO, 2018a). Likewise, water use in Sub-Saharan Africa is growing at a fast pace. Some of the largest users within this region have more than doubled the extraction of water resources. We can highlight Nigeria, where water use doubled, and Mali, where water use quadrupled (FAO, 2018a). The picture in Southern America is somewhat different, as on the whole, water use remained stable or increased only slightly between 1975 and 2010. There are however some exceptions, such as Colombia where water use increased by $50 \%$ between 2000 and 2008 (FAO, 2018a). Finally, we can find different patterns in Asia. The situation in the Middle East, one of the world's most water stressed regions, is quite critical, given the large water use increases from 1975 onwards. Similarly, Southern and Eastern Asia have also experienced an important growth in water use. We can find some examples of this trend in nations such as Pakistan and Vietnam. In the former, water use has grown by $20 \%$ from 1975 . In Vietnam, water withdrawal more than doubled between 1975 and 2010. Nevertheless, water use has remained rather stable during the last two decades in Central Asia.

\section{Factors driving historical water use}

In the following Section we discuss the main drivers of water use in the long term. We will study in depth the main trends and patterns related to the processes of economic growth. More specifically, we will try to explain how population and economic growth, globalisation and water intensity variations have influenced historical water use. It is important to note that in reality these factors are not independent from each other, as 
population growth in developed countries constituted one of the characteristics of modern economic growth. Similarly, globalisation is also clearly related to economic growth. However, addressing each one separately allows us to better understand the causes of the increase in the use of water ${ }^{4}$.

\subsection{Population growth}

Population has been a key driver of water use in the long term (Gleick et al., 2004; Postel, 1999; Shiklomanov and Rodda, 2004). Throughout the twentieth century, the global population increased on average by $1.3 \%$ yearly, rising from over 1.5 billion people in 1900 to approximately 7 billion people in 2010 (Bolt and van Zanden, 2014; Steffen et al., 2015). As Figure 2 shows, the correlation between historical global water use and population is high. However, the historical relationship between these two variables is not completely linear. The global population quadrupled between 1900 and 2010, whereas global water use experienced a six-fold rise. Until the mid-twentieth century, both magnitudes followed a parallel trend. From 1950 to 1980, global water use grew faster than population, but this pattern reversed during the period from 1980 to 2010.

The fast growth of the population throughout the twentieth century was a result of the demographic transition process experienced by an increasing number of countries. This demographic transition has had a diverse chronology (Reher, 2004). In the countries that are currently the highest income earners it took place between the nineteenth and twentieth centuries. The economic growth associated to industrialisation gave rise to a dramatic change in demographic behaviour. However, in less developed countries, the start of the demographic transition was delayed, in general until the second half of the twentieth century, and in many of them it began due to exogenous causes, particularly the import of modern medical and pharmaceutical technology. The economic boom that came later enabled the completion or advancement of this demographic transition which has affected the majority of the world.

\footnotetext{
${ }^{4}$ In other words, although being aware of the complex relationships among population, income, structural and technological change underlying the processes of economic development, our interest here is to isolate the potential contribution of these factors to the water consumption evolution worldwide, making use of a certain ceteris paribus assumption.
} 


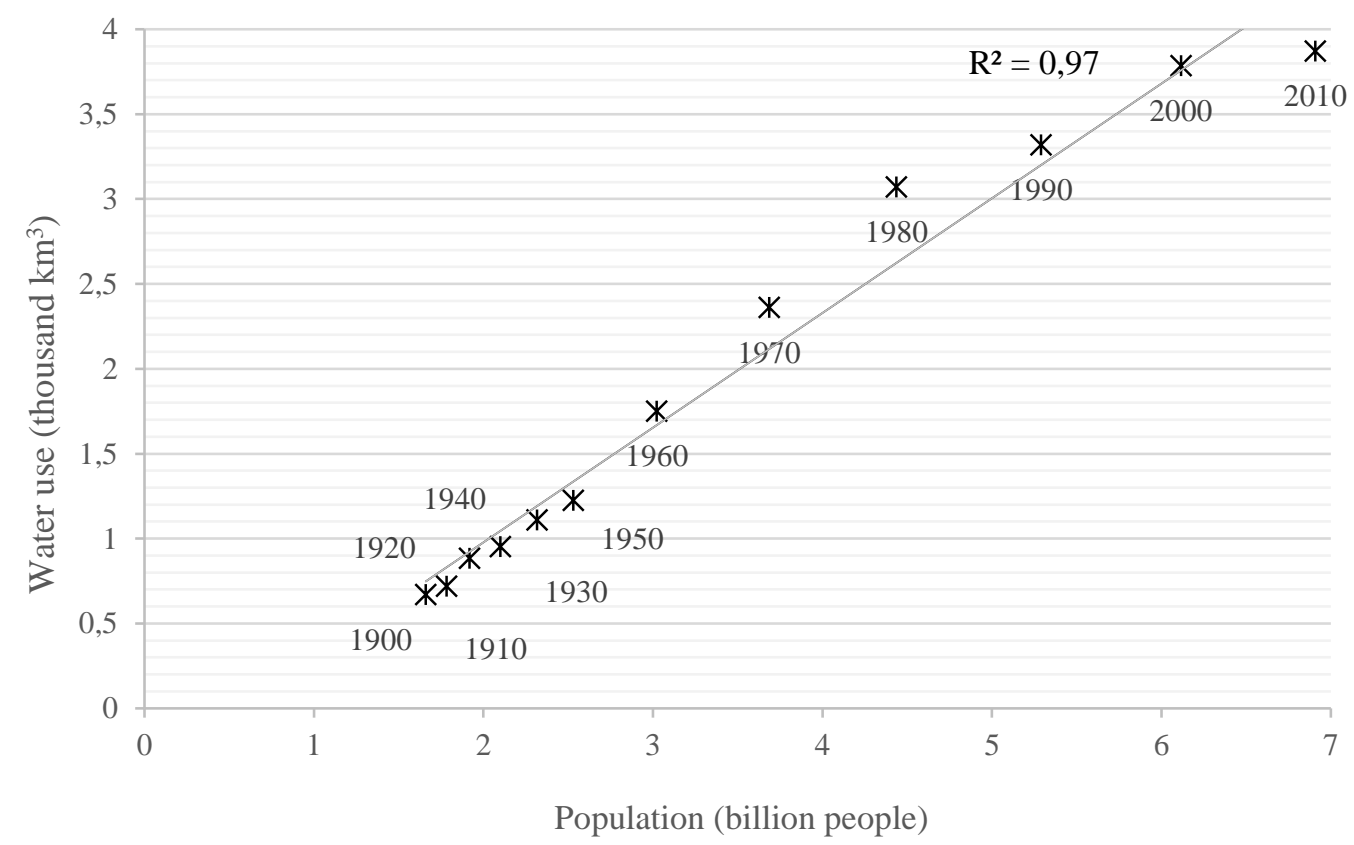

Figure 2: population (billion people) as driver of water use (thousand $\mathrm{km}^{3}$ ), 1900-2010 Source: own elaboration from Steffen et al. (2015).

In OECD countries, annual population growth was around 1\% between 1900 and 2010. Whereas in Western European areas population growth was moderate, in Western Offshoots it was more intense (Bolt and van Zanden, 2014). As Duarte et al. (2014) showed, population growth, although important, has not been the only factor explaining water use trends in OECD states, particularly from 1950. OECD areas represented 10\% of world population growth during the second half of the twentieth century. However, this figure reached around $23 \%$ when considering water use. The five countries belonging to the BRICS area (Brazil, Russia, India, China and South Africa) triggered around $42 \%$ of the increase in global population in the period from 1900 to 2010. This growth was particularly intense between 1950 and 1990, when population more than doubled in this region, namely in China and India. The needs of this larger population caused the water use in the BRICS to increase, which more than tripled during the second half of the twentieth century. Finally, population growth also affected developing countries, mostly from 1950 (Reher, 2004). According to Steffen et al., (2015) population rose in the ROW by a factor of 3.6 during the second half of the twentieth century, even more than water use, which experienced a threefold increase. Within this heterogeneous group, African countries display the largest annual growth rates from 1980, followed by Latin American countries and Asian areas (Bolt and van Zanden, 2014).

These growing populations gave rise to larger demands for energy and food. As for energy, global primary consumption more than tripled throughout the twentieth century (Kander, Malanima and Warde,2013). Today, crude oil is the most highly consumed primary energy source. However, other energy sources, such as hydropower, which are highly intensive in terms of their use of water resources, are also determinant. Hydropower consumption doubled from 1900 to 2010 worldwide and today represents more than $6 \%$ of global energy consumption and around $16 \%$ of the world's electricity supply (BP, 2017; Smil, 2017). In this regard, Mekonnen and Hoekstra (2012) estimate that the water evaporated from reservoirs producing hydropower equals $10 \%$ of the global water footprint of crop production. Population growth has also led to higher food needs. 
However, as we shall see later, in addition to the increase in the demand for food the changes in the composition of the demand have also been significant. As a result, the increase in the production of food and raw agricultural materials was striking in the twentieth century, generating an intense pressure on water resources, particularly in countries with arid or semi-arid climates. Federico (2005) estimated that the global agricultural gross output increased at an annual rate of $0.94 \%$ between 1870 and 1938 . After the Second World War, the growth in production accelerated significantly, reaching an annual rate of $2.69 \%$ (excluding central planning countries) between 1948 and 1960, and $2.27 \%$ between 1961 and 2000. Such a spectacular expansion of production translated into enormous water requirements. There is no global estimate, but for example in the case of Spain, it has been calculated that the increase in agricultural production required $11.3 \mathrm{~km}^{3}$ of virtual blue water between 1860 and 2008 (Duarte et al., 2014b).

\subsection{Economic growth}

In the last two centuries, the sustained economic growth at very high levels compared with pre-industrial levels has radically changed many societies. This growth has been very uneven, as it began with the industrialisation of Great Britain during the eighteenth century and extended in the following century to western countries. Meanwhile, with some exceptions, the rest of the world continued with very low growth rates until well into the twentieth century, which opened a considerable gap in terms of income between the two groups of countries. In the second half of the twentieth century, some developing countries as for example China and India also grew quickly, although the gap between the countries has not closed. Modern economic growth has been characterised by a high and fast increase in per capita income and a profound structural change which transformed essentially agriculturally-based societies into first industrialised economies and, later, predominantly service economies.

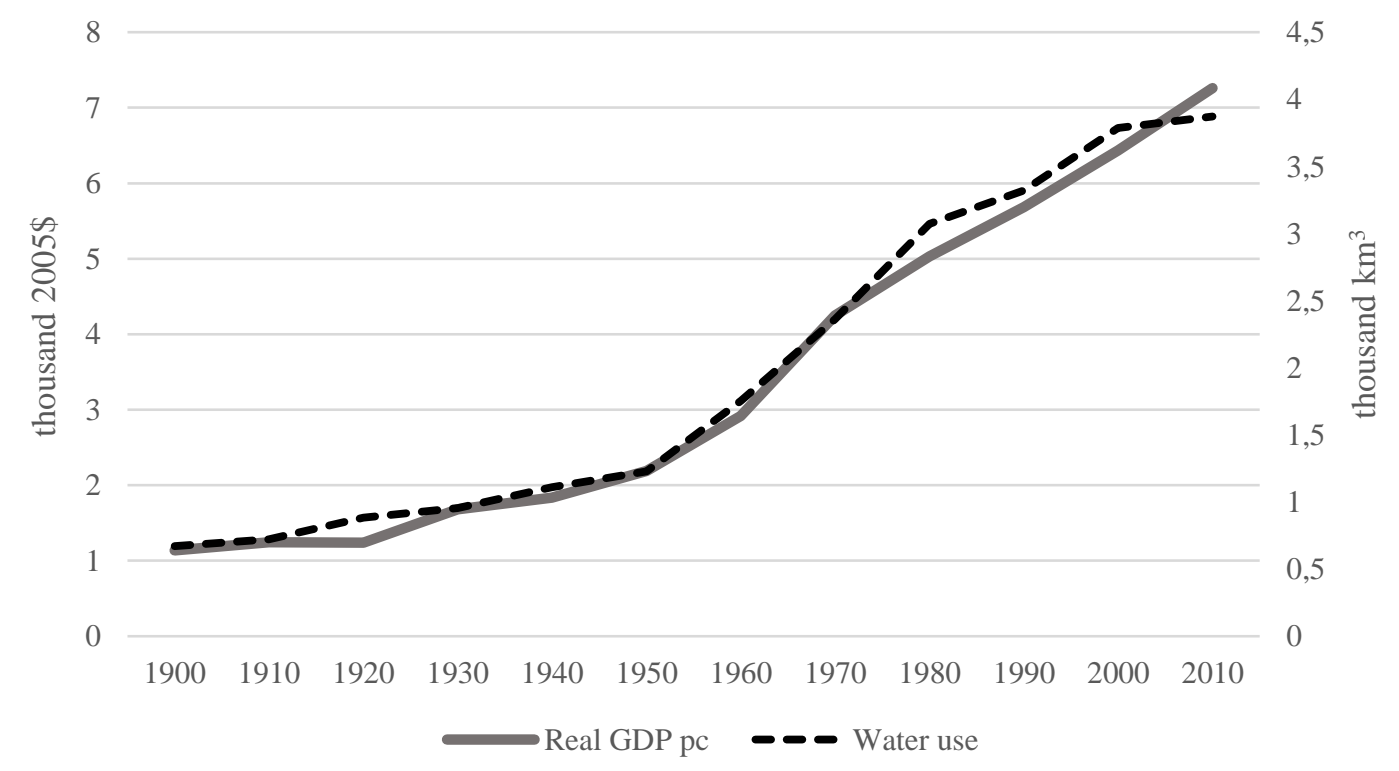

Figure 3: trends followed by per capita GDP (left axis in thousand US\$) and water use (right axis in thousand $\mathrm{km}^{3}$ ), 1900-2010.

Source: own elaboration from Steffen et al. (2015). 
Economic growth has generated an almost parallel increase in the use of water throughout the world, which has had two main drivers: the increase in the population and the increase in per capita income. We have examined the impact of demographic growth on water use, but the increase in income has also played a fundamental role. After breaking down water use according to its driving factors for the whole of the twentieth century, Duarte et al. (2014a) concluded that for the world as a whole, both factors had had a similar impact; until 1980 the impact of income was somewhat higher and from this year the impact of population increase was higher (see Figure 3).

If we examine individual countries (Figure 4), the adjustment is very high in the case of OECD countries, the BRICS and the rest of the world. This does not mean that the increase in income per inhabitant and water use have been similar for all income levels. The evolution of the developed countries reveals a rapid increase in water use in the first phases of their development followed by a considerable stabilisation. In the BRICS and countries in the rest of the world, however, the increases in income occurred at the same time as fast increases in water use which is most probably explained by their strong demographic growth.

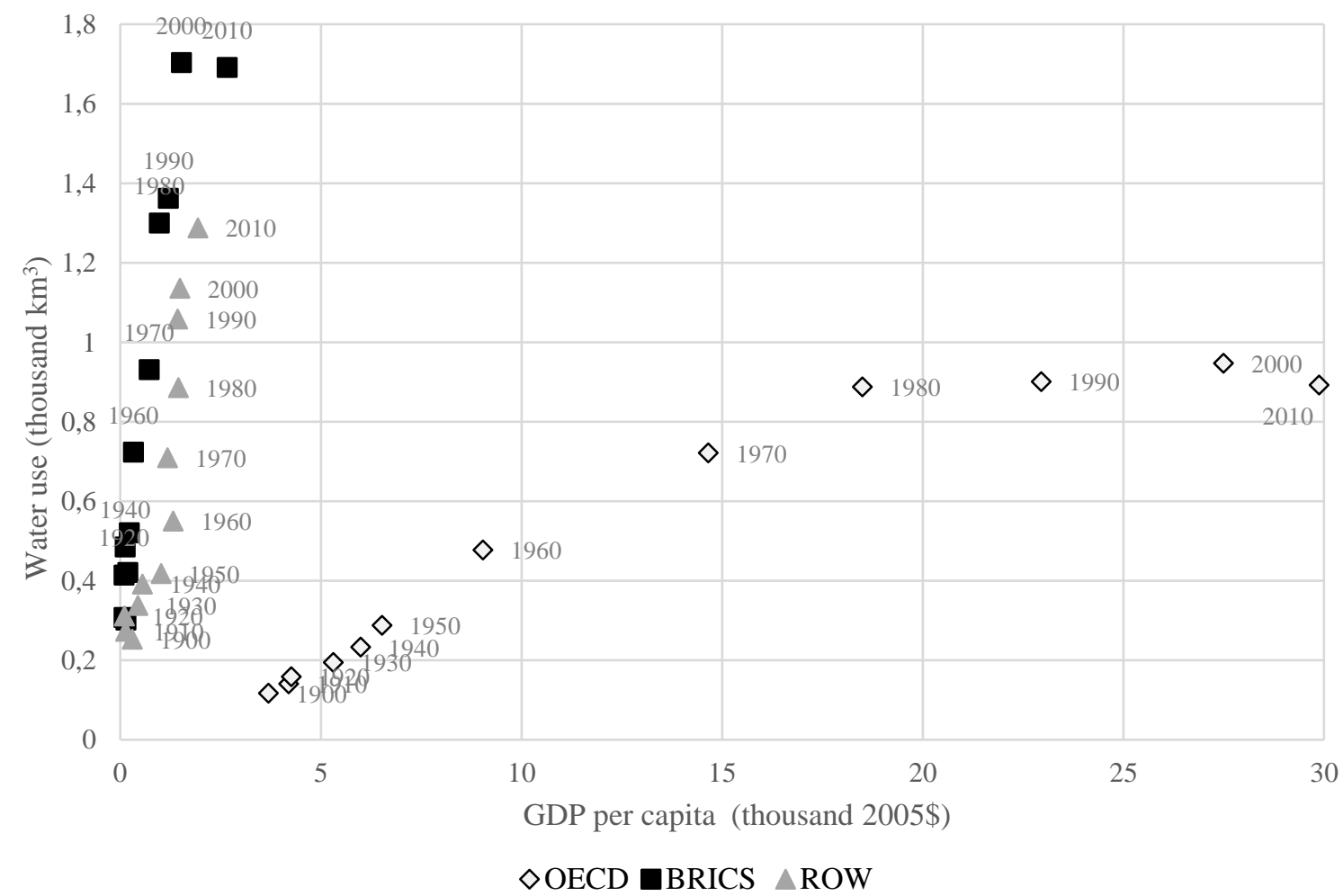

Figure 4: the relationship between per capita income (thousand US\$) and water use (thousand $\mathrm{km}^{3}$ ) by country groups, 1900-2010.

Source: own elaboration from Steffen et al. (2015)

Therefore, it is more appropriate to compare the income per capita growth with water use per inhabitant in order to eliminate the effect of population growth. In this case we can see in Figure 5 that, for the whole of the world, the increase in income also implies an increase in water use which has subsequently begun to decrease in more recent years. Similar results are obtained for OECD countries and the BRICS, although the formers are more interesting due to the strong increases in income taking place throughout the twentieth century. In summary, it seems that there is an environmental Kuznets curve (EKC) for water use. Some empirical studies have highlighted the existence of this curve 
in an inverted U shape (Duarte et al., 2013; Katz, 2015). At the lowest levels of per capita income, a rise in income boosts water use. At this stage, the highest priority is to satisfy basic needs. Subsequently, the improvements in the standards of living lead to changes in dietary patterns incorporating more water-intensive goods like meat and fruit (Goklany, 2002). Besides, industrial development and urbanisation result in a greater and more diverse increase in per capita water use (Duarte et al., 2014a). In the next stage, water use income elasticity becomes negative, with more per capita GDP involving less water use per capita, since technical, managerial and institutional changes boost water use efficiency (Duarte et al. 2014a). In this regard, we can consider higher environmental awareness and regulation, increased health risks, the modernisation of irrigation and economic constraints, among other factors. Following Stern (2004) for the case of emissions, innovations are firstly implemented in developed areas, and then they are introduced in developing countries with a short delay, allowing water use, in our case, to drop in both high-income and emerging countries. 

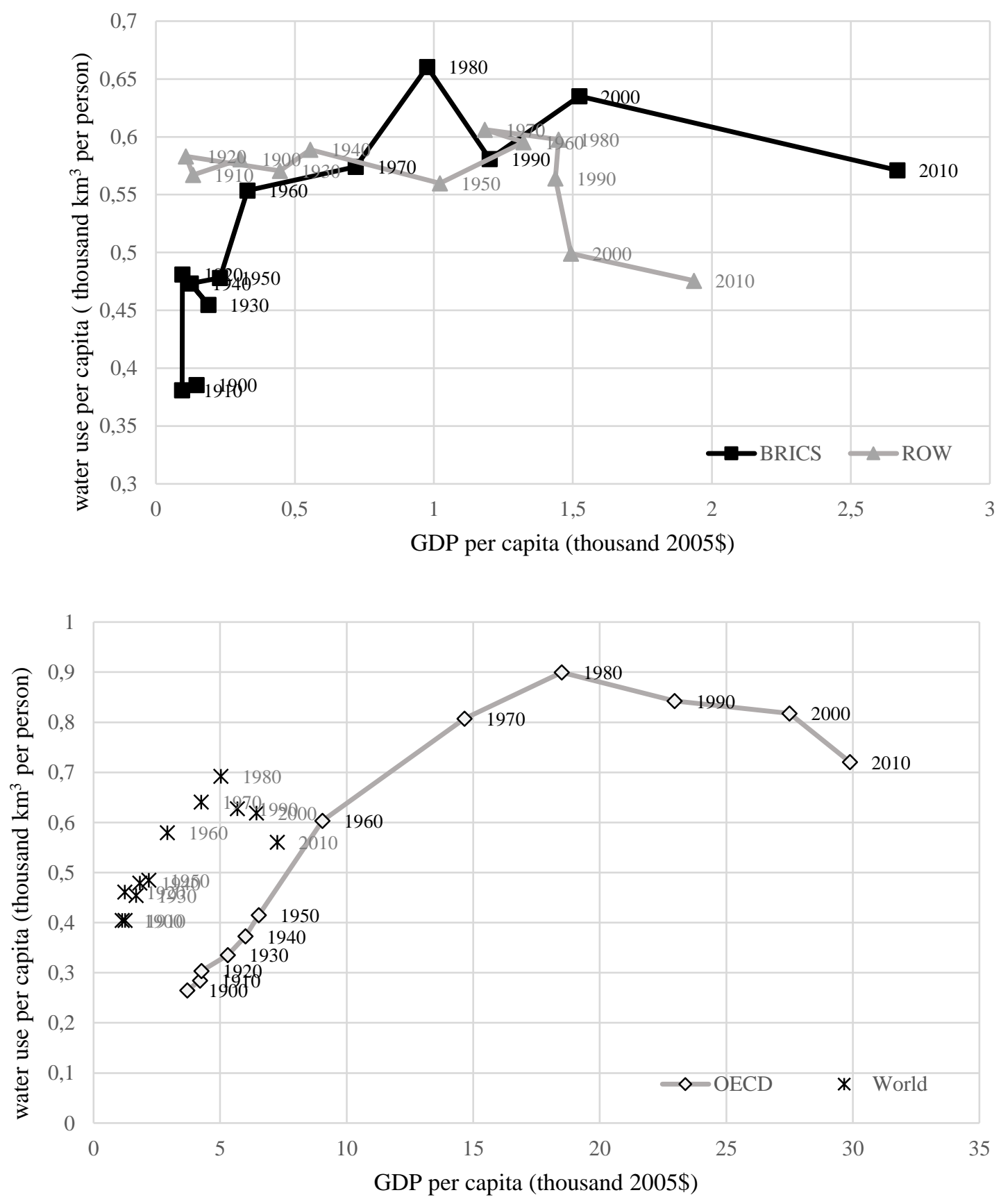

Figure 5: the relationship between per capita income (thousand US\$) and water use per capita (thousand $\mathrm{km}^{3}$ ) by country groups, 1900-2010

Source: own elaboration from Steffen et al. (2015)

Through which channels has the increase in income also generated an increase in water use per inhabitant? From our point of view, the changes in demand resulting from the improvement in income have been fundamental. Furthermore, economic growth has gone hand in hand with a strong urbanisation process on a global scale.

In this regard, rising incomes have not only led to an increase in the demand for many products, but also a change in the composition of this demand. On the one hand, manufactured products have gained enormous weight as the industrial production processes require more water for processing certain products. Industrial production and domestic consumption have required a growing use of energy, mainly derived from the 
combustion of fossil fuels which also necessitates a higher water use, particularly for cooling purposes (Martin and Rubio-Varas, 2018; Sesma, 2019). The strong growth of industrial production has therefore led to an increase in water use which has been estimated to have more than doubled on a global scale between 1950 and 2010 (an increase of $2.9 \%$ per year). This strong increase in the second half of the twentieth century is the result of widely varying trends on a regional level. While the industrial use of water grew in developed countries until 1980, since then there has been a significant decrease. On the other hand, the BRICS and other countries with an expanding industrial production increased their water use enormously for these purposes from the beginning of the 1990s (Flörke et al., 2013).

For the agricultural sector, as well as the growing demand resulting from the possibility of the population to consume a higher quantity of food, dietary changes have also been important. The nutritional transition has led to a decrease in the proportion of foods of plant origin consumed and an increase in the consumption of animal products. Within the foods of plant origin, the basic products, primarily cereals, have lost weight while fresh fruit and vegetables have gained weight. In general, foods with a higher income elasticity have increased their relevance. On the whole, these foods require a much more intensive use of water. Therefore, the kilocalories consumed per person and day increased on a global level between 1961 and 2000 by $20 \%$, due to a strong increase in the developing countries and a much smaller increase in the developed countries. While the consumption of bulk cereals increased by $15.3 \%$, meat consumption increased by $73.7 \%$, that of fruit by $38.4 \%$ and that of vegetable oils by $106 \%$ (Serrano and Pinilla, 2014). Specifically, meat production increased vigorously during the twentieth century (FAO, 2018b). It rocketed in the BRICS countries, multiplying by a factor of seventeen between 1900 and 2010. This trend has important implications for water resources as meat has the largest water footprint of agricultural and food products. As Mekonnen and Hoekstra $(2012,2010)$ show, the water footprint of meat production is about nine times larger than that of bovine meat.

Together with sustained population growth, urbanisation has generated considerable changes in land use, affecting water resources (WWAP, 2015). By 1900 approximately $16 \%$ of global population was living in urban areas. This share rose to $29 \%$ in the mid-twentieth century and $51 \%$ in 2010 . The urban population in OECD countries, which was already $34 \%$ in 1900, gradually increased throughout the twentieth century and today accounts for approximately $77 \%$ of total population. This growing trend was, however, explosive in emerging and developing countries. During the period from 1900 to 1950, the urban population doubled in BRICS and ROW countries. Nevertheless, it was from the mid-twentieth century when the urban population soared in these areas, growing yearly at a rate of over than $3 \%$. Today, the urban population is more than $44 \%$ in BRICS and other developing areas (Steffen et al., 2015). Because of this worldwide urbanisation process, pressures on water resources are increasing, particularly in droughtprone regions (WWAP, 2015). Economic growth has given rise to a lifestyle with a more intensive water use. From the end of the nineteenth century, the expansion of the cities was accompanied by the implementation of services to provide running water and sanitation services which implied a greater use, particularly when it became possible to equip homes with sanitary elements for hygiene or cleaning equipment. When this phase came to an end, domestic water use stabilised or even fell with the use of more waterefficient appliances (washing machines, dishwashers, etc.) and systems that limited flushing or the unnecessary use of water in bathrooms (Flörke et al., 2013). The rising prices of water for domestic consumption also promoted saving. 
The pioneering nature of industrialisation and economic growth explains the importance of the increase in per capita income as a determinant of water use in highincome economies such as those of Europe during the first half of the twentieth century. In contrast, the late implementation by developing countries, such as those in Asia, of the development process explain why it was not until the second half of the twentieth century when per capita GDP displays a larger share than population.

\subsection{Globalisation}

The two waves of globalisation that have taken place over the last two centuries are among the most relevant events in economic history. Market integration, a key element of these globalising processes has led to a strong increase in the movement of goods and factors of production. The increase in trade has exceeded that of production itself, causing the opening up of economies during the globalising phases (and their closure during the collapse of the first globalisation after the crisis of 1929). The increase in trade was brought about by rightward shifts in the supply and demand curves and also by the fall in transaction costs, mainly due to the reduction in transport costs and trade liberalisation processes. The increase in the movement of goods between countries has also given rise to a growing disconnection between the location of production and consumption. Therefore, the increase in the demand for water that we have analysed in the previous Sections has not occurred exclusively or principally in those places where the demand for the goods is located. We could say, on the contrary, that during the two waves of globalisation, there was an increase in the trade of virtual water, that is, of water necessary for the production of exchanged goods. Without a doubt, the trade of virtual water has been concentrated in foods and agricultural raw materials, so we will focus on these sectors.

During the first globalisation, beginning in around 1830, international trade experienced strong growth. Between 1850 and 1913 it grew at an annual rate of $3.24 \%$ (Federico and Tena, 2019). The trade of food and agricultural raw materials grew at a very similar pace, constituting a fundamental part of total trade, as these goods represented approximately half of it (Aparicio et al., 2009). The weight that agricultural trade represented on agricultural production increased significantly, in fact it doubled, which implies that there was a considerable increase in the virtual water exchanged. There are no specific estimates on a global scale regarding its volume, but there is an estimate for Spain for this period which may serve as a guide. This country was one of the main exporters of certain agricultural products such as wine, olive oil or fresh fruit and vegetables (Pinilla and Ayuda, 2009). In Spain, in 1860, agricultural exports represented $5 \%$ of the blue water used in agricultural production. In 1930, this percentage increased to $16 \%$. This increase represented $31 \%$ of the total increase of blue water used throughout this period (Duarte et al., 2014b). In short, such a large increase in trade and the example analysed indicate that the expansion of international trade represented an additional pressure on water resources, and that foreign markets had a growing relevance in the water uses in agriculture. 


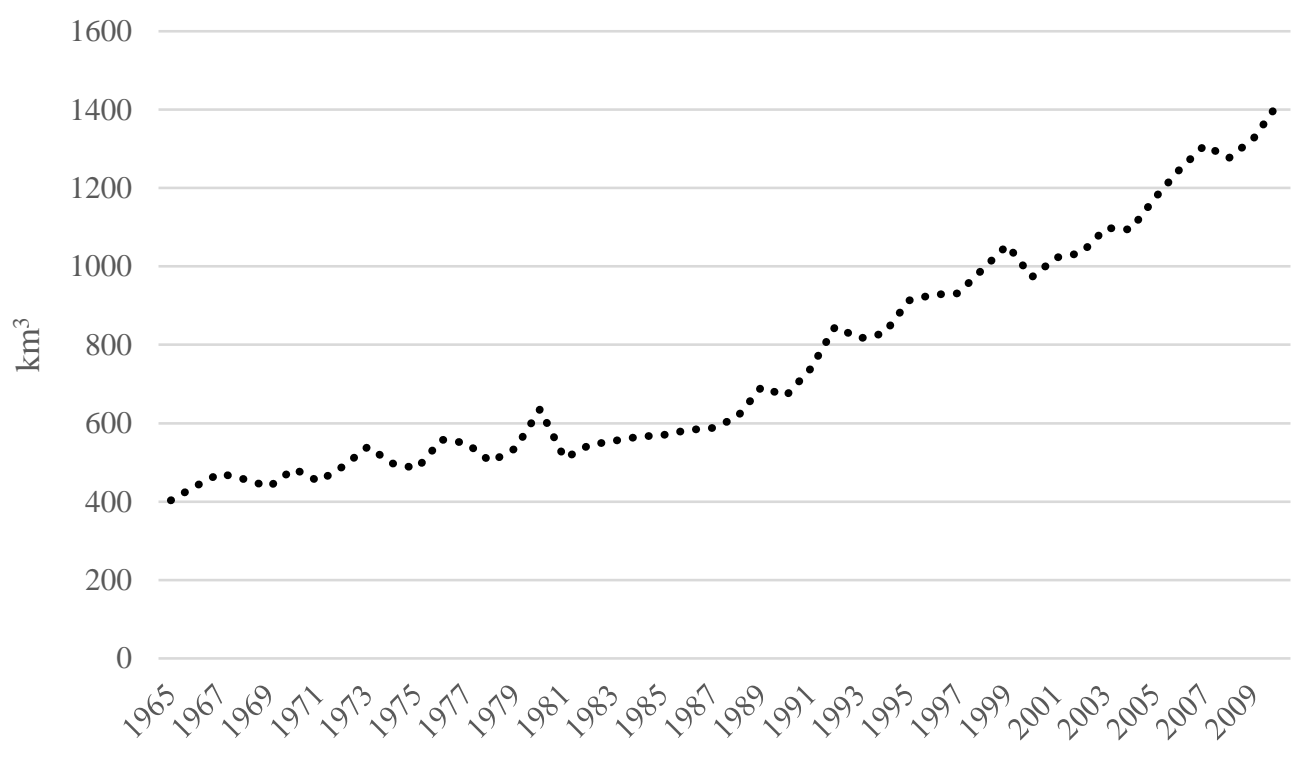

Figure 6: trend followed by virtual water trade $\left(\mathrm{km}^{3}\right)$ in the world, 1965-2010 Source: own elaboration from Duarte et al. (2016b)

In the second wave of globalisation, after the de-globalising interval which occurred due to the depression of the 1930s and the Second World War, international trade grew at an even faster rate than during the first wave. The participation of agricultural products in total exchanged goods reduced drastically, and today they represent less than $10 \%$ (Serrano and Pinilla, 2012). However, from the perspective of its impact on water use, the most important factor is that agricultural trade grew in absolute terms in the second half of the twentieth century, even faster than in the first globalisation, at an annual rate of $4 \%$. Logically, the analysis has contemplated the geographical separation between agricultural production and food consumption. The percentage represented by trade of global production again doubled during this period. Therefore, the growing relevance that the increase in trade has for water use is logical. Between 1965 and 2010, the exchanges of water embodied in agricultural and livestock products increased more than threefold, growing at $2.7 \%$ yearly. This rise was especially intense from 1980 onwards, particularly in the 1990s, with global virtual water trade flows growing at 3.8\% per year (Duarte et al, 2016b). Clark et al. (2015) also showed the growing dependence of countries on foreign water resources in the period 1965 to 2010.

Therefore, we can observe the growing divide between consumer and producer responsibilities regarding water resources, as the consumption of goods and services from other parts in the world embody volumes of water withdrawn in distant places. An illustrative example of this issue is the Spanish food industry, one of the world's leading food exporters. The considerable increase in Spain's net exports led to an increase of over 60\% in blue water consumption between 1960 and 2010 (Duarte et al., 2016a). Hence, the concentration of a significant share of global agricultural production in some of the most arid regions in the world triggers pressing sustainability problems (Cazcarro et al., 2015). These intense and growing global flows of virtual water are not only caused by the traditional determinants of trade, but also the environmental conditions of the different countries, their capacity to provide irrigation water and the size and type of their agricultural specialisation are fundamental for determining their exporting possibilities or their import needs (Fracasso, 2014; Duarte et al., 2019). 


\subsection{Water use intensity changes}

Duarte et al. (2014a) pointed to the declining water use intensity as the main factor behind the levelling-off of global water use occurring from 1980. As Figure 7 shows, the level of water-use per unit of GDP, i.e. water intensity, followed a decreasing trend from 1900 in the world as a whole. The more intense growth of real GDP (measured in constant 2005\$) compared to global water use explains this fact. This means that the world has been historically capable of producing goods and services by gradually using less water per dollar of production. This decline in water intensity would be related to technological developments, investments in infrastructure and changes in water policy that were encouraged, to a large extent, by the increasing competition for water derived from its growing demands.

At the regional scale, water use intensity remained stable in OECD areas during the first half of the twentieth century. In 1950, it started a sustained fall until 2010. Today, three times less water is required to produce a dollar compared to 1900 in the OECD countries. In the case of the USA, for example, water intensity declined modestly up to 1980, but reduced almost threefold between 1980 and 2010 (Donnelly and Cooley, 2015). Emerging and developing areas classified as BRICS and ROWs, experienced a huge decrease in their water use intensity, which are today over 22 and 36 times lower than in 1900 , respectively. Despite these improvements, water use intensity is today roughly eight times larger in BRICS and ROWs than in the OECD. To illustrate this, between 1980 and 2010 water use intensity reduced by a half in China, decreased by a factor of four in India and fell more moderately in Brazil.

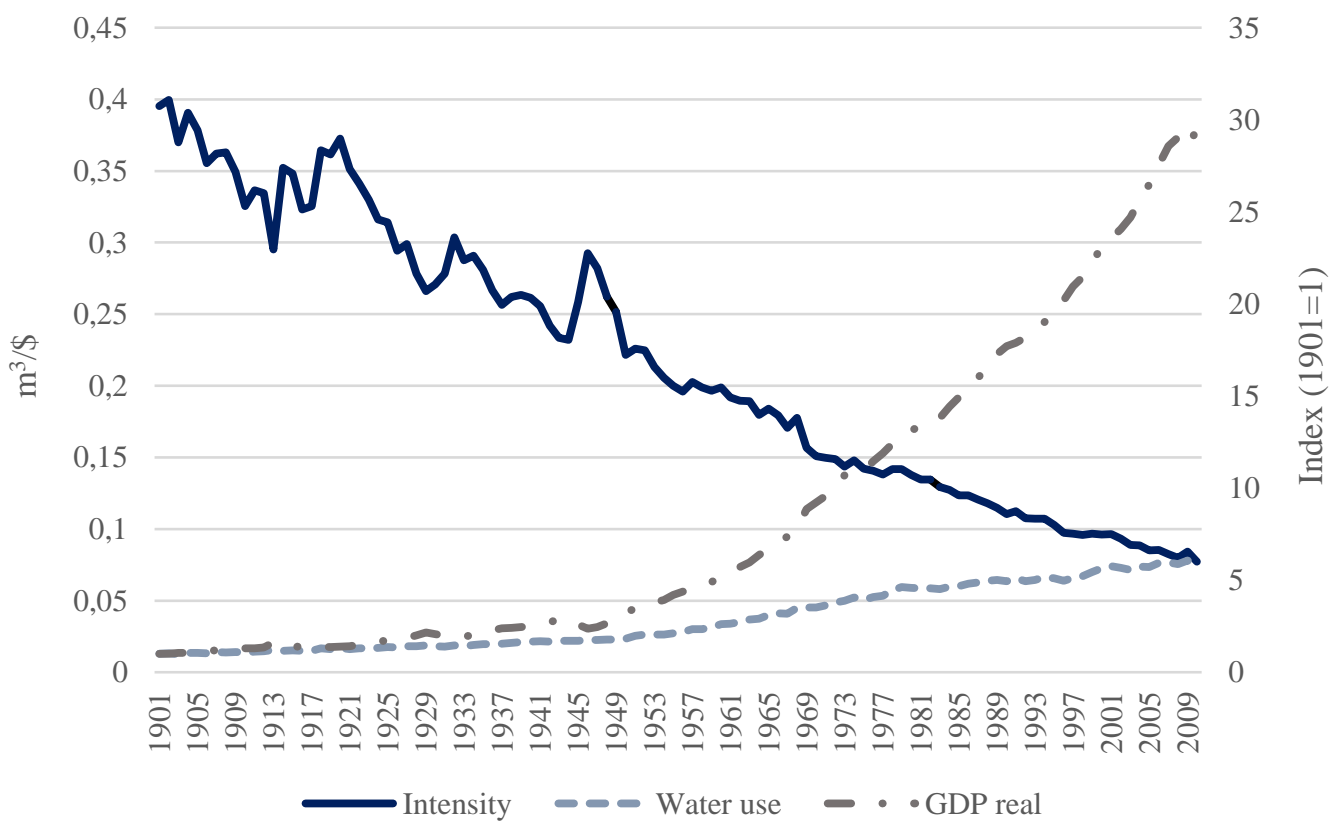

Figure 7: global water use intensity $\left(\mathrm{m}^{3} / \$\right)$ (left axis) and trend followed by global water use and real GDP (index, 1901=100) (right axis), 1901-2010Source: own elaboration from Steffen et al. (2015)

At the global level, some of the most representative technological innovations have occurred in relation to irrigation. As Evans and Sadler (2008) acknowledge, irrigation has been modernised in many aspects such as pumping, filtration, distribution, drainage, 
power sources, scheduling, water conservation, among others. Until the 1970s the expansion of irrigated agriculture was based on gravity-fed and flood systems. However, from then on, more water efficient techniques were implemented. According to Postel (2012), over the last two decades, the area irrigated with drop or other micro-irrigation techniques has increased by a factor of 6.4. These methods can diminish the volume of water used by over 70\%, compared with traditional methods such as flood or furrow. The most significant gains in micro-irrigation in the world have been achieved in China and India, where, over the last twenty years the increase was around 88-fold and 111-fold, respectively (Postel, 2012). In the USA, the transition has also been intense. By 1984, in the western states, $71 \%$ of irrigation water was applied using gravity techniques. In 2013, this percentage had fallen to $41 \%$ (Schaible and Aillery, 2016). Worth mentioning is California where today, 62\% of the irrigated area applies micro-irrigation (Postel, 2012). These irrigation technologies benefited from the development of low-cost aluminium and PVC pipes (Evans and Sadler, 2008) and their adoption was encouraged more by yield improvements and soil restrictions than by the enhancement of water conservation (Schaible and Aillery, 2016).

On the other hand, at the end of the twentieth century, the construction period of the large reservoirs was coming to an end, at least in the developed countries. Together with the end of public funding for large dams and reservoirs, the subsidies for the modernisation of irrigation have grown in recent years. This has been the case of Spain, the EU leader in terms of irrigated area, where the public (and also private) investment for upgrading irrigation systems has been enormous since 2002, covering 1.5 million of hectares (Gómez-Limón and Villanueva, 2017; López-Gunn et al., 2012). Similarly, state conservation programmes have been implemented to promote the restoration of water ecosystems in developed countries such as the USA, where river restoration projects have grown exponentially since 1990 (Schaible and Aillery, 2016). All these changes reflect a strong reorientation in the management of water resources towards demand-driven policies. This inflexion has been guided by the growing cost of supply-side measures and by an increasing environmental awareness. The redirection of water policies has been conducted through laws such as the European Water Framework Directive (WFD) implemented in 2000. This proposed an integrated management of water resources at the river basin level by promoting the coordination and public participation of stake-holders and introduced water pricing mechanisms (Zikos and Hagedorn, 2016). A similar direction has been followed in the USA, where many states acknowledge that environmental flows and water markets are used for the reallocation of water among different uses (Schaible and Aillery, 2016; Debaere and Li, 2017).

Finally, since 1980, considerable improvements in the efficiency of water use and water savings in the domestic and industrial sectors have occurred. Flörke et al. (2013) find a modest increase in domestic water use on a global level during the period from 1980 to 1995 . This would be related to the introduction of advances in the domestic sector, such as water-efficient appliances, the pricing of water or the utilisation of water meters. As for industry, technological developments in cooling towers (Flörke et al., 2013) or the transition of industrial processes towards circulating water supply systems would have also contributed to the reduction of water intensity (Shiklomanov, 2000). In addition, the shift away from water-intensive industries such as steel production or chemical manufacture to services has also reduced the intensity of water use, mostly in developed countries (Gleick, 2002). 


\section{4. $\quad$ Responses from the supply side}

For a long time, the main response to the growing demand for water was the development of infrastructures in order to guarantee water availability for agricultural and urban uses on a supply-based strategy. In the twentieth century, the construction of hydraulic infrastructures was mainly undertaken by governments. In the case of European countries or the United States, in the nineteenth century a largely classical liberal approach was taken towards the development of hydraulic works. The public participation in the construction of hydraulic infrastructures increased enormously throughout the twentieth century. This responded to the slow pace with which the private initiative undertook these works in some countries or to the size of the investments that were necessary once the simple or least costly works had been carried out. Furthermore, the low profits derived until then by the private companies were also decisive as was the growing hostility of the users towards them (Pisani, 1992; Hundley, 1992; Anderson, 1998; Pinilla, 2006).

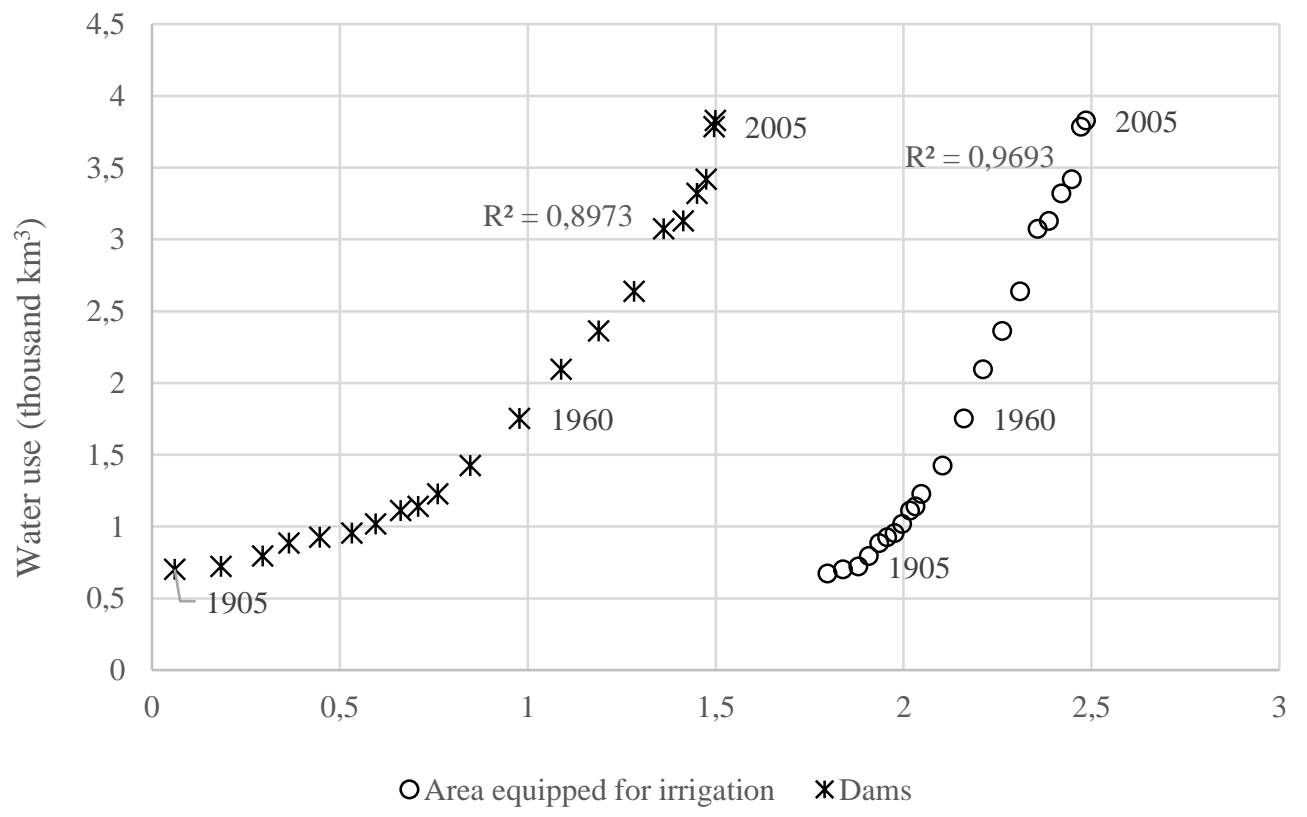

Figure 8: area equipped for irrigation (thousand hectares in logs) and dams (thousand dams in logs) as drivers of water use (thousand $\mathrm{km}^{3}$ ) in the world, 1905-2005

Source: own elaboration from Steffen et al. (2015) and Siebert et al. (2015)

Two types of infrastructures have been fundamental for the expansion of the supply of water: the construction of reservoirs and the building of other works necessary to extend the irrigated farming area. The construction of reservoirs has enabled the regulation of the flows of the water basins, preventing or reducing floods. They also made the production of electricity possible together with the supply of water for urban use and the extension of irrigation in agriculture. The building of dams experienced a large increase during the twentieth century. These macro projects, mostly subsidised by governments, were designed to meet the growing human water needs. As we can see in Figure 8 , the correlation between the increase in water use and the construction of reservoirs is very high, as the latter have substantially increased the availability of water. From the 1970s and 1980s, the construction of water infrastructures levelled off in developed countries, as their large economic, social and environmental costs started to be recognised (Gleick, 2003; Moran et al., 2018). However, important projects are being 
developed in river basins such as the Mekong, Congo and Amazon basins, all located in emerging economies (Moran et al., 2018).

However, the construction of reservoirs has not been enough to adequately respond to the demand for water. In the case of hydroelectricity, the laying of electricity lines to connect the consumption centres with the production plants has been necessary. For urban supply it has also been necessary to construct canals to supply water and build treatment plants. However, the most important undertaking has probably been the enormous effort to transport the water from the reservoirs to the fields, which has required the construction of primary and secondary canals and the works to prepare the fields. In this case we can also observe an intense correlation between water use and the expansion of the area equipped for irrigation (Figure 8), which is logical given the high proportion that agricultural uses represent of total water use. In this regard, the expansion of irrigation systems has contributed significantly to the increase in food production. It was also necessary for the efficient use of the agricultural technologies of the green revolution.

\section{Conclusions}

The threat to the sustainability of water resources is one of the most serious global concerns that humanity will have to face in the coming decades. Climate change coupled with intense pressure on resources is already causing severe changes in global hydrological conditions, seriously threatening the availability and quality of water in many regions. This worrying situation is expected to get even worse over the next few decades, affecting the availability of drinking water in large areas of the world, threatening the sustainability of agriculture and therefore global food sustainability.

Over the last two centuries, human action has been identified as the main driver of the impacts on natural resources in general, and on water in particular. The intensification of these pressures is related to the needs of a growing population, together with industrialisation, urbanisation and globalisation processes. Despite the importance of these socioeconomic factors, there are not many studies in the literature that discuss the relationship between water pressure in different regions of the world and their processes of economic development and population change from a long term perspective. This is the main approach of this study.

The work reviewed the evolution of water use over the last century and its relationship with the dynamics of population, economic and technological factors. We shed light on the relation and on the impact of economic growth on water demand at a global scale, also focusing on how growth processes observed in different regions of the world have conditioned water demands. This review of economic processes over the past century throughout the world can provide us with valuable information to understand current trends and anticipate future pressures. The in-depth study of the evolution of water withdrawal and its relation to the variables of interest reveals important conclusions and paves the way for new debates.

The results show an overall growth of global water use over the last century which was particularly pronounced during the second half of the twentieth century and seemed to have slightly moderated in recent years. However, there has been a high degree of heterogeneity between world regions and periods. Until the 1970s, the greatest growth in water use was linked to the economic and population growth of the OECD countries, 
while in recent decades, it has moderated, giving way to the BRICS countries as the main drivers of water use worldwide (strongly conditioned by the expansion processes of India and China). In the twenty-first century, water withdrawal continues to grow, particularly in the ROW countries. This trend is undoubtedly related to the evolution of the world population, which implies greater demands of water for consumption and, mainly, food. However, the data show that the relationship between water use and population growth is not linear, with other factors contributing to easing the increase in recent decades.

Thus, the global rise observed in water pressure is accompanied by other highly relevant data. Currently, the global per capita use of water is similar to that observed in the 1960s. Taken together, both trends show us the importance that demographic patterns have had, and currently have, on global water demand, also imposing significant regional heterogeneity. This pressure can be associated not only with the scale, but also with the type of demands made by the population, which are strongly linked to disposable income (in general, there is a change in consumption patterns towards water-intensive products as income increases). However, the data show that not only the population, but also the productive model, economic growth, and efficiency in the use of water strongly condition this water pressure. The years between the 1950s and 1980s constituted a decisive period in the industrial intensification of the OECD economies, in the processes of urbanisation, and in the trade expansion of these countries, which acted all as strong drivers of water demand. Important processes of technological change that improve water efficiency in the agricultural sector were also gradually incorporated. Therefore, the subsequent decades have been characterised by significant increases in per capita income, which, however, have allowed a better relationship with per capita water use, resulting in an inverted $U$ shape in the OECD economies.Notably, this U-inverted pattern is also observed for BRICs and ROW, with certain peculiarities. In these areas the turning points for income levels are much lower than those observed for the OECD, which would suggest that the improvements made to efficiency, that took time to achieve in the rich countries, were generalised in the other countries of the world at a faster pace. In other words, the data suggests a worldwide generalisation of efficiency improvements, allowing a reduction in the use of water in relation to the generation of income, also contributing to a global decoupling of economic growth in relation to water withdrawal. However, particular behaviours can be found, and as Distefano et al. (2018) have shown, some countries have even worsened their water efficiency over this period.

Along these same lines, the results show the important role that structural and technological changes have played in improving water productivity. Structural change is fundamentally associated to the tertiarisation processes of economies and the generation of products with greater added value. Technological change, on the other hand, is related to improvements in refrigeration and recirculation systems in the industrial sector, improvements in urban pipelines, the pricing of urban use, but fundamentally, to the introduction of precision irrigation technology in agriculture, that followed the expansion of irrigated agriculture in the second half of the twentieth century, mainly in Europe and America.

However, in many countries this agricultural expansion was based on the development of important hydraulic infrastructures. They were mostly publicly owned or heavily subsidised, which guaranteed the supply of water with little or no effect on the pricing of the resource and did not reflect the real costs of supply. In recent decades, the important long-term economic, social and environmental impacts of these infrastructures have been acknowledged and these supply policies seriously questioned. In this regard, 
considerable efforts have been made in the twenty-first century to redirect policies towards so-called demand policies focused on the responsible use of water resources and the incorporation of stakeholders in the management and design of price mechanisms for water. However, highly questionable large-scale water infrastructures are still being planned, mainly in developing countries.

Finally, despite the advances made over the last few decades and the positive expectations that could be derived from the technical improvement and the greater environmental awareness of consumers, water management throughout the world reveals worrying international trends, which represent major challenges for research and citizenship in the coming years.

On the one hand, population growth and economic development perspectives in developing areas continue to threaten global water resources. According to UN Water (2015), by 2030, the urban population in Africa and Asia will double. Moreover, income increases linked to economic growth also anticipate changes in consumption patterns towards diets that require a more intensive in the use of water, posing an added threat to the sustainability of the systems. In this context, one of the main challenges is the rising global heterogeneity of water pressures, which, together with climate irregularity and climate change, may lead to serious effects for certain populations and economies, reducing their water access and growth opportunities. On the other hand, less than $4 \%$ of the world's irrigated land is equipped with micro-irrigation systems. Clearly, the irrigation revolution has a long way to go (Postel 2012). Finally, in our globalised world, we cannot forget that the pressure on water resources has, increasingly, a local-global dimension. In this sense, an increasing part of water use in arid and semi-arid regions is related to the expansion of international trade, generating products that are consumed far from the production areas. The observed rising trend in virtual water in the world, particularly intense from the 1980s, indicates a clear globalisation of water pressures, a growing dependence on foreign water resources and a strong relationship between consumption, production and water pressures worldwide.

Raising economic, social and environmental complexity demands integrated visions of water issues and shared responsibility, involving consumers, producers, water authorities and policymakers in the design and management of sustainable and fair local and global conditions for economic growth, helping to ensure the long-term sustainability of natural resources.

\section{References}

Alcamo, J., Flörke, M., Märker, M., 2007. Future long-term changes in global water resources driven by socio-economic and climatic changes. Hydrological Sciences Journal 52, 247-275.

Alcamo, J., Döll, P., Henrichs, T., Kaspar, F., Lehner, B., Rösch, T., Siebert, S., 2003. Development and testing of the WaterGAP 2 global model of water use and availability, Hydrological Sciences Journal, 48, 3, 317-337.

Anderson, T. L. 1998. Water, Water Everywhere but Not a Drop to Sell. In: J. L. Simon (ed.), The State of Humanity, Oxford, Blackwell, 425-433. 
Aparicio, G., Pinilla, V., Serrano, R., 2009. Europe and the international agricultural and food trade, 1870-2000", in P. Lains and V. Pinilla (eds.), Agriculture and Economic Development in Europe since 1870, Routledge, London, 52-75.

Bolt, J., van Zanden, J.L., 2014. The Maddison Project: collaborative research on historical national accounts. Economic History Review 67, 627-651.

BP, 2017. BP Statistical Review of World Energy, BP Statistical Review of World Energy.

Carr, J.A., D’Odorico, P., Laio, F., Ridolfi, L., 2012. On the temporal variability of the virtual water network. Geophysical Research Letters 39.

Cazcarro, I., Duarte, R., Martín-Retortillo, M., Pinilla, V., Serrano, A., 2015. How Sustainable is the Increase in the Water Footprint of the Spanish Agricultural Sector? A Provincial Analysis between 1955 and 2005-2010. Sustainability 7.

Debaere, P., Li, T., 2017. The Effects of Water Markets: Evidence from the Rio Grande, 2017 Annual Meeting, July 30-August 1, Chicago, Illinois, Agricultural and Applied Economics Association.

Distefano, T., Scott, K., 2017. Are we in deep water? Water scarcity and its limits to economic growth. Ecological Economics 142, 130-147.

Distefano, T., Riccaboni, M., Marin, G., 2018. Systemic risk in the global water inputoutput network. Water resources and economics 23, 28-52.

Donnelly, K., Cooley, H., 2015. Water Use Trends in the United States. Oakland.

Duarte, R., Pinilla, V., Serrano, A., 2013. Is there an environmental Kuznets curve for water use? A panel smooth transition regression approach. Economic Modelling 31, 518-527.

Duarte, R., Pinilla, V., Serrano, A., 2014a. Looking backward to look forward: water use and economic growth from a long-term perspective. Appl. Econ. 46, 212-224.

Duarte, R., Pinilla, V., Serrano, A., 2014b. The water footprint of the Spanish agricultural sector: 1860-2010. Ecological Economics 108, 200-207.

Duarte, R., Pinilla, V., Serrano, A., 2016a. Globalization and natural resources: the expansion of the Spanish agrifood trade and its impact on water consumption, 19652010. Regional Environmental Change 16,259-272.

Duarte, R., Pinilla, V., Serrano, A., 2016b. Understanding agricultural virtual water flows in the world from an economic perspective: A long term study. Ecol. Indic. 61, 980990.

Duarte, R., Pinilla, V., Serrano, A., 2019. Long Term Drivers of Global Virtual Water Trade: A Trade Gravity Approach for 1965-2010. Ecological Economics 156, 318326.

Ercin, A. E., Hoekstra, A. Y., 2014. Water footprint scenarios for 2050: A global analysis. Environment International 64, 71-82.

Evans, R.G., Sadler, E.J., 2008. Methods and technologies to improve efficiency of water 
use. Water Resources Research 44.

Falkenmark, M., 2013. Growing water scarcity in agriculture: future challenge to global water security. Philosophical Transactions of the Royal Society A: Mathematical, Physical and Engineering Sciences 371.

FAO, 2018a. AQUASTAT [WWW Document]. Food Agric. Organ. United Nations.

FAO, 2018b. FAOSTAT: Statistical database. [WWW Document]. FAOSTAT Stat. database.

Federico, G., 2005. Feeding the world: an economic history of agriculture, 1800-2000. Princeton University Press, Princeton.

Federico, G., Tena-Junguito A., 2019. World trade, 1800-1938: a new synthesis. Revista de Historia Económica-Journal of Iberian and Latin America Economic History, 37, $1,9-41$.

Fekete, M., Wisser, D., Kroeze, C., Mayorga, E., Bouwman, L., Wollheim, W.M., Vörösmarty, C., 2010. Millennium Ecosystem Assessment scenario drivers (19702050): Climate and hydrological alterations. Global Biogeochemical cycles, 24, 1 12.

Flörke, M., Kynast, E., Bärlund, I., Eisner, S., Wimmer, F., Alcamo, J., 2013. Domestic and industrial water uses of the past 60 years as a mirror of socio-economic development: A global simulation study. Global Environmental Change 23, 144156.

Fracasso, A., 2014. A gravity model of virtual water trade. Ecological Econonomics 108, 215-228.

Gerten, D., Hoff, H., Rockström, J., Jägermeyr, J., Kummu, M., Pastor, A. V., 2013. Towards a revised planetary boundary for consumptive freshwater use: role of environmental flow requirements. Current Opinion in Environmental Sustainability $5,551-558$.

Gleick, P.H., 2003. Global Freshwater Resources: Soft-Path Solutions for the 21st Century. Science, Science 302 (5650), 1524-1528.

Gleick, P.H., 2002. Water management: Soft water paths. Nature.

Gleick, P.H., 2003. Global Freshwater Resources: Soft-Path Solutions for the 21st Century. Science (80-. ).

Gleick, P.H., Cain, N., Haasz, D., Palaniappan, M., Hunt, C., Srinivasan, V., Moench, M., Wolff, G., Henges-Jeck, C., Kiparsky, M., 2004. The World's Water 2004-2005: The Biennial Report on Freshwater Resources. Island Press, Washington, D.C.

Gómez-Limón, J.A., Villanueva, A.J., 2017. La Política Agraria Común y la modernización de regadíos, in: Berbel, J., Gutiérrez-Marín, C. (Eds.), Efectos de La Modernización de Regadíos En España. Cajamar Caja Rural, Almería.

Hundley, Jr., N., 1992. The Great Thirst. Californians and Water, 1770s-1990s, University of California Press, Berkeley and Los Angeles. 
Kander, A., Malanima, P., Warde, P., 2013. Power to the People. Energy in Europe over the Last Five Centuries. Princeton University Press, Princeton.

Katz, D., 2015. Water use and economic growth: Reconsidering the Environmental Kuznets Curve relationship. Journal of Cleaner Production88, 205-213.

Kummu, M; Guillaume, J. H. A., de Moel, Eisner, HS., Flörke, M., Porkka, M., Siebert, S., Veldkamp, T. I. E., Ward, P. J., 2016. The world's road to water scarcity: shortage and stress in the 20th century and pathways towards sustainability. Nature Scientific Reports, 6:38495, 1-16.

López-Gunn, E., Mayor, B., Dumont, A., 2012. Implications of the Modernization of Irrigation Systems, in: Water, Agriculture and the Environment in Spain.

Martín, D.S., Rubio-Varas, M.D.M. Freshwater for Cooling Needs: A Long-Run Approach to the Nuclear Water Footprint in Spain, 2017. Ecological Economics, $140,146-156$.

McKinsey, 2009. Charting our water future: economic frameworks to inform decisionmaking. Munich: 2030 Water Resource Group, McKinsey Company.

Mekonnen, M.M., Hoekstra, A.Y., 2010. A global and high-resolution assessment of the green, blue and grey water footprint of wheat. Hydrol. Earth Syst. Sci. 14, 12591276.

Mekonnen, M.M., Hoekstra, A.Y., 2012. The blue water footprint of electricity from hydropower. Hydrological Earth System Sciences 16, 179-187.

Mekonnen, M.M., Hoekstra, A. Y., 2012. A Global Assessment of the Water Footprint of Farm Animal Products. Ecosystems, 15, 3, 401-415.

Moran, E.F., Lopez, M.C., Moore, N., Müller, N., Hyndman, D.W., 2018. Sustainable hydropower in the 21st century. Proceedings of the National Academy of Sciences 115(47), 11891-11898.

Pinilla, V., 2006. The Development of irrigated agriculture in twentieth century Spain: a case study of the Ebro Basin. International Business Review 54,1, 122-141.

Pinilla, V., Ayuda, M.I., 2009. Foreign markets, globalisation and agricultural change in Spain", in V. Pinilla (ed.) Markets and Agricultural Change in Europe from the 13th to the 20th century, Brepols Publishers, Turnhout, 173-208.

Schor, J., 1992. To Reclaim A Divided West. Water, Law, and Public Policy 1848-1902, Alburquerque, University of New Mexico Press.

Postel, S., 1999. Pillar of Sand: Can the Irrigation Miracle Last? W. W. Norton \& Company, New York.

Postel, S., 2012. Drip Irrigation Expanding Worldwide [WWW Document]. Natl. Geogr. Mag. URL https://blog.nationalgeographic.org/2012/06/25/drip-irrigationexpanding-worldwide/

Reher, D.S., 2004. The demographic transition revisited as a global process. Population Space Place 10, 19-41. 
Rockström, J. et al. (2009). A safe operating space for humanity. Nature 461, 472-475

Schaible, G.D., Aillery, M.P., 2016. Challenges for US Irrigated Agriculture in the Face of Emerging Demands and Climate Change, in: Competition for Water Resources: Experiences and Management Approaches in the US and Europe.

Schewe, J. et al., 2014. Multimodel assessment of water scarcity under climate change. Proceedings of the National Academy of Sciences 111, 3245-3250.

Serrano R., Pinilla V., 2012. The Long-Run Decline in the Share of Agricultural and Food Products in International Trade: A Gravity Equation Approach of its Causes. Applied Economics 44, 32, 2199-2210

Serrano R., Pinilla, V., 2014. Changes in the structure of world trade in the agrifood industry: the impact of the home market effect and regional liberalization from a long term perspective, 1963-2010. Agribusiness: an International Journal 30, 2: 165183.

Sesma-Martín, D., 2019. The River's Light: Water Needs for Thermoelectric Power Generation in the Ebro River Basin, 1969-2015. Water 11, 441.

Shiklomanov, I.A., 2000. Appraisal and Assessment of world water resources. Water International 25, 1, 11-32.

Shiklomanov, I.A., Rodda, J.C., 2004. World Water Resources at the Beginning of the Twenty-First Century. Cambridge Univ. Press.

Siebert, S., Kummu, M., Porkka, M. et al. 2015. Historical Irrigation Dataset (HID).

Smil, V., 2017. Energy Transitions: Global and National Perspectives, Praeger.

Soligno, I., 2019. Spatial and temporal patterns of global freshwater use for food production and trade. Diss. Politecnico di Torino.

Steffen, W., Broadgate, W., Deutsch, L., Gaffney, O., Ludwig, C., 2015. The trajectory of the anthropocene: The great acceleration. The Anthropocene Review 2, 1, 81-98.

Stern, D.I., 2004. The Rise and Fall of the Environmental Kuznets Curve. World Development 32, 1419-1439.

Tamea, S., Carr, J.A., Laio, F., Ridolfi, L., 2014. Drivers of the virtual water trade. Water Resources Research 50, 17-28.

Tello, E.; Ostos, JR., 2012. Water consumption in Barcelona and its regional environmental imprint: a long-term history (1717-2008). Regional Environmental Change, 12, 2, 347-361

Vörösmarty, C. J., Leveque, C. \& Revenga, C., 2005. Chapter 7: Fresh Water. In: Millennium Ecosystem Assessment, Volume 1: Conditions and Trends Working Group Report, 165-207. Island Press, Washington, DC

Vörösmarty, C.J., Green, P., Salisbury, J., Lammers, R.B., 2000. Global water resources: vulnerability from climate change and population growth. Science 289, 5477 
WWAP (United Nations World Water Assessment Programme), 2015. The United Nations World Water Development Report 2015: Water for a Sustainable World; facts and figures., Paris, UNESCO.

Zheng, C., Liu, J., Cao, G., Kendy, E., Wang, H., Jia, Y., 2010. Can China cope with its water crisis? - Perspectives from the North China Plain. Ground Water 48, 3, 350354.

Zikos, D., Hagedorn, K., 2016. Competition for Water Resources From the European Perspective, in: Competition for Water Resources: Experiences and Management Approaches in the US and Europe. Elsevier, 19-35. 